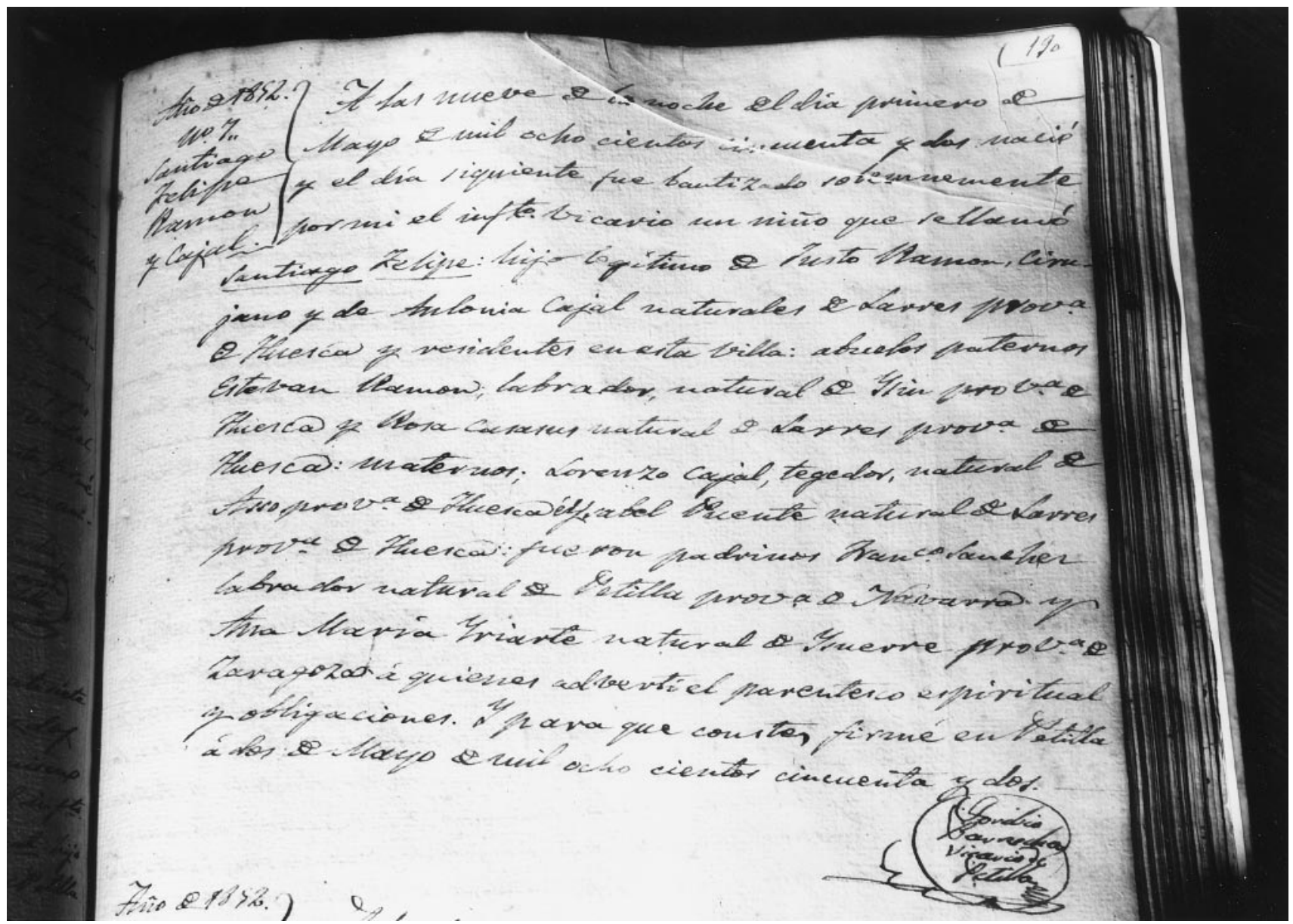

Figure. The section mentioning Cajal's birth in the Birth Registry of Petilla, province of Navarre, Spain. This registry is currently kept at the Archives of the Diocesan Commission for the Cultural Heritage, Jaca, Spain.

\section{Birth certificate of Santiago Ramón y Cajal}

Eduardo Martinez-Vila, MD, PhD, José C. Masdeu, MD, PhD, Pamplona, Spain

Birth certificate of Santiago Ramón y Cajal, 1906 Nobel Laureate in medicine, in recognition of his work on the structure of the nervous system, on the 150th anniversary of his birth on May 1, 1852.

Birth certificate translation: At nine in the evening of the first day of May, eighteen hundred and fifty two, an infant boy was born and on the following day was solemnly baptized by myself, the vicar, and was thus named Santiago Felipe. He is the legitimate son of Justo Ramón, a surgeon, and of Antonia Cajal, both born in Larres, town of the province of Huesca, and residents of this town (Petilla).
The paternal grandparents are Esteban Ramón, a farmer born in Isún and who now resides in Huesca, and Rosa Casasus, born in Larres, province of Huesca. The maternal grandparents are Lorenzo Cajal, a weaver born in Asso, province of Huesca, and Ysabel Puente, born in Larres, province of Huesca. The godparents are Francisco Sánchez, a farmer born in Petilla, province of Navarre, and Ana María Iriarte, born in Ysuerre, province of Zaragoza, both of whom were reminded of their spiritual kinship and obligations. And thus stated, I sign this certificate in Petilla, on the second day of May eighteen hundred and fifty two.

Signed: Toribio Barnecha, Vicar of Petilla

Address correspondence and reprint requests to Dr. Eduardo Martínez-Vila, Clínica Universitaria de Navarra, Pio XII s/n, Pamplona 31008, Spain; e-mail: emartinezv@unav.es 


\section{Neurology}

\section{Birth certificate of Santiago Ramón y Cajal \\ Eduardo Martínez-Vila and José C. Masdeu \\ Neurology 2002;59;148}

This information is current as of July 9, 2002

\section{Updated Information \&} Services

Permissions \& Licensing

Reprints including high resolution figures, can be found at: http://n.neurology.org/content/59/1/148.full

Information about reproducing this article in parts (figures,tables) or in its entirety can be found online at:

http://www.neurology.org/about/about_the_journal\#permissions

Information about ordering reprints can be found online:

http://n.neurology.org/subscribers/advertise

Neurology ${ }^{\circledR}$ is the official journal of the American Academy of Neurology. Published continuously since 1951, it is now a weekly with 48 issues per year. Copyright . All rights reserved. Print ISSN: 0028-3878.

Online ISSN: 1526-632X.

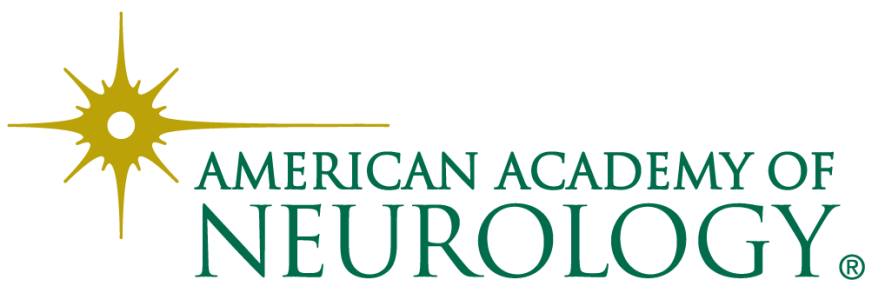

